\title{
HASAN BASRİ (ÇANTAY) VE SES GAZETESI*
}

Doç. Dr. Nesimi YAZICI

Bir toplumun fertlerini, kendi kişisel menfaatlerinin ötesinde, mensup. oldukları milletin hayrı istikametinde, ne ölçüde yönlendirebilmek mümkün olursa, o milletin istikbali de o ölçüde garanti altına alınmıș olur. Bu hakikat dolayısıyla, büyük Türk milletinin yetiştirdiği değerli evlâtlarını tanımak ve yeni nesillere tanıtmak da önemli bir görev olarak karşımızda durmaktadır. Milletimiz, uzun tarihi boyunca, kendisine değişik alanlarda hizmet etmiş sayısız büyük kișilere sahiptir. Kurtuluş Savaşında Gönen ve Çevresi Sempozyumu vesilesiyle biz de sizlere, böyle bir bakış açısı ile, bu dönemin ve bu bölgenin bir değerli evladından, Hasan Basri (Çantay)' dan ve onun tarafından 17 Ekim 1918 ile 13 Mart 1919 tarihleri arasında yirmi iki sayı olarak neşredilen Ses gazetesinden bahsedeceğiz. Böylece bu sempozyumda hizmetlerini ve isimlerini anmaya imkân bulduğumuz/bulamadığımız, kurtuluşumuzun ve bağımsızlığımızın temellerinde gayretleri kanları hatta canları bulunan ecdadımızın ruhlarını da, onlardan birini anmak suretiyle, şâdetmeye çalışacağız.

\section{HASAN BASRİ (ÇANTAY)'NIN HAYATI}

Mücadelesi, sıkıntısı ve başarısı ile; acısı tatlısı ile; çocukluğu, gençliği, orta yaşlılığı ve yaşlılığı ile seksen yıla yaklaşan uzun bir ömrü, bir sempozyumda, bir tebliğin küçük bir bölümü olarak takdim etmek gerektiğinde, hangi ölçüler kullanılabilirse biz de o ölçüler ve o sınırlar içerisinde H. Basri Hoca'nın hayatını sizlere sunmak, daha doğru bir ifade ile onun hayatından önemli gördüğümüz kesitleri ortaya koymaya çalışacağız. Bu bakımdan gerçekten hatırlanması ve hatırlatılması gereken bazı noktalar atlanmış olursa, bunu önemsiz görmemize değil, imkânsızlığımıza vermenizi istirham edeceğim.

* Bu metin 5 Eylül 1993'te Gönen'de toplanan Kurtuluş Savaşında Gönen ve Çevresi Sempozyumu'na bildiri olarak sunulmuştur. 
Hasan Basri (Çantay), çevresinde bilgi ve güzel ahlâkı ile tanınan, tüccar Çantay-zâde Halil Cenabî Efendi ile Kepsut yöresinde isim yapmıș Sincanlı ailesinden, iyilik severliği ve bir çok güzel özelliği dolayıs1 ile tam bir müslüman Türk hanımı olarak tanınan Hatice Hanımın tek erkek evlâdı olarak 18 T. Sâni 1303/30 Kasım 1887 de Balıkesir' de doğdu.

Hasan Basri (Çantay), oldukça varlıklı bir ailenin üç kızla birlikte tek erkek evlâdı olarak, dönemi ailelerinin büyük bir kısmında görüleceği üzere, azamî bir itina ve dikkatle, bir sevgi ve şef kat çemberi içerisinde çocukluğunu geçirdi. Yine dönemin geçerli şartlarına tabi olarak küçük yaşta öğretime başladı. Bundan sonra onun öğretim hayatının, ilk dönemi örgün öğretim kurumlarında olmak üzere, bir ömürü eksiksiz doldurduğunu ifade etmek yerinde olacaktır. Bu arada Balıkesir'in tanınmış alimlerinden Arap Hoca'dan ilk öğrenimini görmüș müteâkiben İbtida-yı Kebir denen ilkokul, Rüştiye ve İdadi'de öğretimine devam etmiştir. Fakat 1903 'te 16 yaşında iken babasının vefatı üzerine İdadî öğretimini yarım bırakmak zorunda kalmıştır. Bir çok kişi şu veya bu nedenle ögretimine devam etmek imkânı bulamadığında, geçim derdine düşer, hayat mücadelesinin zorlukları altında ezilir ve artık öğrenmek ve öğretmekten uzak bir hayat sürer. Hasan Basri (Çantay) ise bunun aksine, örgün öğretim dediğimiz teşkilâtlı okullara gitme fırsatını kaybettikten sonra da, çeşitli vesile ve vasıtalarla kendisini yetiștirmeye ve bildiklerini hem ilim, hem de aksiyon olarak çevresindekilere intikâl ettirmeye devam etmiştir.

Hasan Basri Hoca'nın doğumu sırasında ve çocukluk yıllarında Balıkesir iki büyük felaketle karşılaşmıştı. Bunlardan birincisi onun doğduğu yıl (8 Ocak 1887) meydana gelen ve çarșıda yüzden fazla dükkanın yanmasına neden olan, sonuçta oldukça büyük bir ekonomik çöküntüyü getiren yangın felaketi idi. İkincisi ise aradan on yıl geçtiğinde yine bir Ocak ayında, 16 Ocak 1897'de meydana gelen ve çok sayıda can ve büyük çapta mal zayiatına sebep olan depremdi. Bu büyük deprem ileride Hasan Basri Hoca'nın tanınması yönünden bir hayra da vesile olacaktır. Nitekim aradan altı yıl geçtiğinde 1903'te Balıkesir Mutasarrıfı Ömer Ali Bey 1897 depreminde harap olan șehrin en büyük camii Zağnos Mehmet Paşa Camii'ni tamir ettirerek, adeta yeniden yapılmış bir büyük mabet halinde Balıkesir'lilerin hizmetine sunduğunda, genç Hasan Basri bunu konu edinen aruz vezniyle elli beyitlik bir şiir yazarak Mutasarrıfa gönderdi. Şiirden sahibinin yeteneğini ve taşıdığı zekâ pırıltılarını keşfetmekte gecikmeyen Mutasarrıf Ömer Âlî 
Bey bu sırada babası öldüğünden öğrenimine ara vererek, ailesinin geçim yükünü sırtlanmak durumunda kalan genç Hasan Basri'yi seksen kuruş maaşla Nafia dairesinde görevlendirdi.

Hasan Basri Bey, buradaki görevi sırasında mutasarrıf Ömer Âli Bey'in yakın ilgisini görerek yarım kalan öğretimini değişik vasıtalarla tamamlama imkanın buldu. Balıkesir Mevlevihane Medresesi' nde Ragıp-zade Ahmet Naci Efendi'den Arapça öğrendi. İleride Müstecaplı-zade Halil ve Balıkesir Müftüsü Osman Nuri Efendilerden de Farsça öğrenecektir. Böylece eski kültürümüzün kaynaklarına inebilme imkânını elde edecek olan Hasan Basri Hoca, Ömer Âlî Bey'den sonra Balıkesir Mutasarruflığına getirilen dönemin tanınmıș ilim ve fikir adamlarından Mehmet Ali (Ayni) Bey'in de yakın ilgi ve desteğini gördü. Şimdi görevi mutasarrıfın hemen yanında $\mathrm{T}$ a h ri r a t $\mathrm{K}$ a le$\mathrm{m} \mathrm{i} \mathrm{K}$ a t i pli ğ i ydi. Bu sırada diğer konular yanında bilhassa da Edebiyat, Hukuk ve Felsefe ile meșgul oluyor, durmadan okuyor, fırsat buldukça da yazıyordu.

Ragip-zade Ahmet Naci Efendi'nin vefatından sonra bir süre de Müftii Kodanaz-zade Hacı Ahmet Efendi'den okudu. Artık zorunlu dersleri bitirmişti ve bu durumū gösteren icâzetini almıştı. Hasan Basri Hoca, bugünkü diploma karşılığı olan icâzetnamesini almakla öğrenimine ara verecek kișilerden değildi. Nitekim Meșrutiyet yıllarında Balıkesir Mutasarrıfı olan Mümtaz Bey'den Hukuk, Maliye ve İktisat dersleri okudu. Böylece gelişmekte olan yeni ilimlerdeki eksikliklerini giderdi.

Hasan Basri (Çantay), bir devlet memuru olarak görevini yaptığı bu yıllarda, ülke bir büyük cihan savaşının yıkımına uğramaktaydı. Bu sırada onu parçalanmaya çalıșılan aziz vatanı bir bütün olarak koruyabilme çabalarının hem silahlı bir mücahidi, hem de eriştiği bilgi ve kültür düzeyiyle çeviresini millî birlik ve beraberlik yönünde uyarmaya çabalayan bir fedakâr gazeteci olarak görmekteyiz.

Hasan Basri (Çantay)'nin hayatının ancak belirli noktalarını hatırlatmakla yetinmek durumunda olduğumuz bu konușmada, onun 30 Ekim 1918 de imzalanan Mondros Mütarekesi'nin ortaya çıkarttığı durum karşısındaki tutumuna değinmekte yarar görmekteyiz. Bilindiği gibi bu belgenin bazı maddelerini kendilerine göre yorumlayan İtilâf devletleri, savașta elde edemedikleri aziz vatanımızın bazı bölgelerini yer yer işgal etmeye bașlamışlardı. Bu ülkenin evlâtları da çeşitli çıkış yolları armakta idiler. İşte bu sırada İzmir Vali ve Bölge Komutanı 
Nurettin Paşa, bir beyanname yayınlıyarak 1919 Mart'ında İzmir, Manisa, Aydın, Denizli ve Balıkesir'den gönderilecek delegelerle bir kongre toplanmasını teklif etti. Nurettin Paşa'nın M üdâfaa-yı Hukuk-1 Osmaniye Kongresi olarak düşündüğü bu kongre, aslında ilk Redd-i İlhak Kongresi olacaktı. Bu kongreye katılacak Balıkesir temsilcileri arasında Hasan Basri Bey de vardı.

17 Mart 1919'da toplanacak kongre için 15 Mart Cumartesi günü Balıkesir'den hareket etmek üzere iken Hasan Basri Bey takip edildiğini öğrendi. İtilâf Devletleri biraz sonra söz konusu edeceğimiz Ses gazetesindeki yazılarından rahatsızdılar. Manisa'da trenden indi. Bir bașka vasıta ile İzmir'e ulaștı. Nurettin Pașa ile İzmir'in Yunanlılarca işgal edileceği haberleri ve buna karşı alınabilecek tedbirleri görüştü. Anadolu gazetesi idarehanesinde Celal Bayar'la görüştü. O gece uyumayan Hasan Basri Bey, Kongreye sunulmak üzere bir rapor hazırladı. $\mathrm{Bu}$ raporda; Venizelos tarafındån ileri sürülen İzmir ve çevresinin $\mathrm{Yu}$ nanlılara ait olduğu iddialarını çürütüyordu. Bu sırada tutuklama emri geldiğini öğrendiğinde kaçtı. Bu kaçaklık tam olarak dokuz ay on gün sürecektir.

Hasan Basri Bey, Kaçaklık günlerinde ülkenin kurtuluşu için mücadele azmiyle daha da bilendi. Kepsut çevresinde silahlı birlik oluşturdu.

Kurtuluş savaşı sırasında ve sonrasında; bir mücahit, bir fikir adamı, devleti kuran Birinci Mecliste mebus, hâsılı yaşadığı sürece vatanın ve milletin emrinde onların istikbâllerinin mükemmelen temini hedefine yönelik her türlü çabayı göstermekten geri durmayan Hasan Basri (Çantay), bu fedâkârane çalıșmalarına rağmen "Tefâhüre vesile aramadık, vazifemizi yapmaya çalıştık" diyecek derecede de mütevazi, "uzak -yakın tarihe bakın Balıkesir'den devlet-millet haini çıkmamıştır." diyecek kadar da dava arkadaşlarına, hemşehrilerine, milletine güvenen bir kișiydi.

Hasan Basri (Çantay), Birinci Meclis'in feshinden sonra bir daha siyasete katılmadı. Kalan, hayatını önce Balıkesir'de ve son dönemlerini de İstanbul'da ilim, ibadet ve çeșitli sosyal faaliyetlerle meșgul olarak geçirdi.

Yetmiş sekiz ylllık ömrünü hicrî tarihle 1384 Recebinin son günü (3 Aralık 1964) de noktalayan ve İstanbul'da Edirne Kapı Şehitliği'nde medfun bulunan Hasan Basri (Çantay), millî șairimiz Mehmet Akif ile 1908 'lerden başlayan bir yakın dostluğun da sahibidir. Nitekim 
biraz da bu dostluğun meyvesi olarak İzmir'in işgali ve Balıkesir içinde tehlike çanlarının çalmakta olduğu bir sırada Balıkesir'e gelen Mehmet Akif, Zağnos Paşa Camii Kürsüsünden; "Ey Balıkesir'liler! güzel yurdumuzu çiğnetmeyiniz. Savunmanız meşrudur, sebat ediniz, yürüyünüz.” diyecektir. Bu dostluk o derece ileri merhalelere ulaşmıştır ki, Birinci Meclis'te üye olarak bulunan bu iki arkadaş birbirinden manen ayrılmadıkları gibi maddeten de hiç uzak kalmaz, aynı sırayı paylaşırlardı. Bu sevgi dolayısıyladır ki büyük șair, Yunan işgalinin Bursa ve yöresindeki elîm etkileri üzerine yazdığı pek meșhur olan Bülbül şiirini "Basri Bey oğlumuza" ifadesiyle ona ithaf etmiştir. Bu vesile ile hatırlanabilecek bir husus da kendisiyle iftihar ettiğimiz ve bağımsızlığımızın en önemli nişanelerinden biri olduğuna şüphe etmediğimiz İstiklal Marşı'mızı, ikramiye ve müsabaka gibi endişelerle yazmaktan çekinen Mehmet Akif'e, bu yolda en büyük telkin ve desteğin Hasan Basri Çantay'dan geldiğidir.

Hasan Basri (Çantay) okuduklarını yazıya döken bir kişiydi. Çok sayıda makale, şiir ve kitap telif etmiştir. Makalelerin bir kısmını kendinin çıkardığı Balıkesir, Karasi, Yıldırım, Ses, Zafer-i Milli gibi gazetelerle Türk Dili, Sebilï'r-Reşad, Sırat-1 Müstakim, İslam gibi dergilerde yayınlandı. Basılı eserleri arasında; Kur'ân-ı Hakim ve Meâl-i Kerim, Müslïmanlıkta Himaye-i Etfal, Cihad, Akifname Şiirlerim, Türk Edebiyatı, Atalarımız Konuşuyor, Ticari İkrar, Kalendername, Maneviyat-1 Askeriye Dersleri, Ülkü Edebiyatı'nı saymak mümkündür. $\mathrm{Bu}$ arada basılmamıs oniki eser bulunmaktadır.

\section{SES GAZETESI}

Ses gazetesi Hasan Basri (Çantay)'nin Balıkesir'de 17 Ekim 1918 ile 13 Mart 1919 tarihleri arasında, Ancak 22 sayısını yayınlayabildiği haftalık bir gazetedir. Bununla birlikte bu gazete Hasan Basri (Çantay)' nin de neșrinde emeği bulunan ilk gazetedir, ne de onun makalelerinin yayınlandığı tek süreli yayın organıdır. Bu nedenle H. Basri (Çantay)'ın bütünüyle elinden çıkan ve İstiklâl mücadelemizde önemli yeri bulunan bu gazeteye geçmeden önce, onun gazeteciliği üzerinde, hiç değilse genel çizgileriyle, durmakta yarar vardır.

Hasan Basri (Çantay)'nin gazetecilik geçmişi 1908'lere yani İ k i nc i M eşr u ti y e t yıllarına kadar gider. Bu sırada yirmi yaşını yeni geçmiş olan H. Basri (Çantay), uzun bir baskı döneminden sonra ortaya çıkan hürriyet ortamından istifadeyle, gerek başkent ve gerekse taşrada büyük bir hamle yapan matbuatın içerisinde yer alır. Onu ilk olarak Cemil Çavuş'un daha önce kapanıp şimdi tekrar açılmış bulunan 
matbaasında Nasihat adlı bir gazeteyi çıkarırken görürüz. Çok kısa ömürlü olduğu tahmin edilen bu gazeteden sonra 15 Eylül 1325 / 28 Eylül 1909'da Balıkesir adlı bir gazeteyi çıkarmaya başlar. Balıkesir 31 K. Sâni 1327/ 13 Şubat 1912'ye kadar yaklaşık ikibuçuk sene H. Basri (Çantay)'nin yönetiminde çıkarıldıktan sonra matbaanın sahibi Cemil Çavuş'a devredilmiştir.

Gerek Nasihat ve gerekse Balıkesir gazetelerindeki çalışmaları s1rasında, buralarda ilmî, edebî, tarihî, ictimaî, hukukî konularda yazıları yayınlanan $\mathrm{H}$. Basri (Çantay), bu arada gazetecilik mesleğinin inceliklerini de büyük ölçüde öğrenmiș bulunuyordu. Nitekim yine Cemil Çavuş'un matbaasında 11 Şubat 1327 / 24 Șubat 1912 ile 3 Temmuz 1328 / 16 Temmuz 1912 arasında haftalık olarak çıkarılan Yıldırım gazetesini onun daha itinalı bir biçimde neşrettiğini görürüz.

Hasan Basri (Çantay) 14 Nisan 1330/27 Nisan 1914'den itibaren yarı resmi olarak tekrar neşredilmeye başlanan Karesi gazetesinin neşredilmesinde de görev aldı. Daha sonra tamamıla resmî Vilâyet gazetesi olarak yayınlanan bu gazetede $\mathrm{H}$. Basri (Çantay), değișik sahalarda, döneminde ilgiyle okunan çok sayıda makâle neșretti.

H. Basri (Çantay), Birinci Cihan Savaşından yenik çıktığımız ve memleketin istikbalinin son derece karanlık göründüğü bir dönemde milletimize hakkın ve hakikatin sesini duyurmak için çıkardığı Ses gazetesinden sonra, Zafer-i Milli gazetesinin çıkışına da etkili bir biçimde katkıda bulunmuştur. Bizzat veya bilvasıta çıkardığı bu gazeteler yanında H. Basri (Çantay) Doğru Söz, İzmir'e Doğru, Türk Dili, İslam ve bilhassa da Surat-1 Müstakim, Sebilï'r-Reşad gibi süreli yayınlarda neşrettiği çok sayıdaki makâlesi dolayısıyla da diğer meziyetleri yanında, iyi bir gazeteci olarak tanınmaya ve tanıtılmaya lâyık bir şahsiyettir.

Hasan Basri (Çantay)'ın gazeteciliği konusuna kısaca değindikten sonra şimdi Ses gazetesini değerlendirebiliriz, Ses gazetesi 17 Ekim 1918 ile 13 Mart 1919 tarihleri arasında ancak yirmiiki sayı yayınlanabilen, son sayısı müstesna 2 'şer sahifelik $57 \times 40 \mathrm{~cm}$. ebadında 1 kuruş (sonsayı 4 sayfa 100 para)ya satılan haftalık bir gazetedir. Vilâyet matbaasında basılan Ses, bir süreli yayın olarak değişik yönlerden incelenebilirse de biz özellikle de onun muhtevası, ele aldığı konular ve etkileri üzerinde durmaya çalışacağız.

Ses gazetesinin ilk ve son sayılarının çıkış tarihleri dikkate alınırsa, bu dönemin yakın tarihimiz açısından ne derece anlamlı bir devre 
olduğu kendiliğinden anlaşılır. Birinci Cihan Savaşı'nda Osmanlı Devletinin mensup olduğu grup mağlup olmuş, İtilaf devletleri başarılar1nın meyvelerini toplama, önce savaşi durdurma, sonra da barışa geçme çabası içerisindedirler. Nitekim Ses'in ilk sayısının çıkışından 13 gün sonra Mondros Mütarekesi imzalanacaktır. Ses gazetesi yayınına, H. Basri Hocanın İzmir'e gitmek üzere 15 Mart 1919'da Balıkesir'den ayrılması, müteakiben de dokuz ayı geçen bir süre kaçaklığı nedeniyle son vermiștir. Bilindiği gibi aradan iki ay geçince de önce İzmir, daha sonra Ayvalık Yunanlılarca işgal edilmiş, tehlike bizatihî Balıkesir için de ortaya çıkmıştır. İşte böyle bir ortamda toplum ne durumda ise, geçmişin aynası durumundaki bir süreli yayın olarak Ses gazetesinde onu görmek mümkündür. Bu bakımdan Ses kolleksiyonu, bir tarihî belgeler serisidir. Aynı zamanda ülkenin ve milletin bu en sıkıntılı döneminde onun evlatlarına, yalnızca onun hayrını göstermek için hangi fikirler ele alınıp işlenebilirse, işte Ses gazetesinde de bu fikirler ele alınmış ve işlenmiştir. Bu nedenle uzun ve yenilgiyle bitmiş bir savaş sonrasında Türkiye geneliyle birlikte, özelde Balıkesir ve çevresini görmek, tanımak; böyle bir zamanda fikir üreten, vatanını ve milletini çok seven bir aydın kişinin ikazlarını, yol göstermelerini bilmek, yer yer çığlıklarım duymak isteyenler Ses gazetesini incelemek durumundadırlar. Yakın bir gelecekte başlaması kaçınılmaz olan Milli Mücadele'nin ilk kıvilcımları da Ses gazetesinde pırıldar.

Ses'in hedefi, yayın prensipleri ve gazetecilik anlayışı ilk sayısında yer alan Hasan Basri (Çantay)'a ait Gideceğimiz Yol başlıklı baş makalede genişçe açıklanmıştır. Bu makalede ülkenin içinde bulunduğu şartlar gösterildikten sonra; yıllarca süren harbin bütün kötülükleri yanında, ülkenin kendi kendine yetmesi gereğini kavrama açısından biraz da faydalı olduğu ifade edilmektedir. Dış ticaret büyük ölçüde durduğundan kendi yağımızla kavrulmak durumunda kalınmış, bu sayede üretim ve yerli malı kullanımı artmış, iç ticaret gelişmiştir. "Fakat bu uyanma ve tanıma içinde birçok hirslar, ihtiraslar ve ahlaksızlıklar da sokulabilmiştir. Kasalarımızı dolduran kağıt paralar eski ruh temizliğimizi -maalesef- bozdu." İnsanlar içinde biz biz yerine ben ben diyenler çoğaldı. Kalpler katılaştı, sanki yardımlaşma ve dayanışma gibi güzel huylar göğe çekildi. Tabiatıyla bu durumda halkın çoğunluğu büyük sıkıntılar altında ezildi. Bunların sonucunda toplumun temellerini sarsan diğer gelişmeler ortaya çıktı. "Köylüler bir taraftan eşkiyallğın zulümleri, ihtikârcıların dolaplart yüzünden, öbür, taraftan, kendi bilgisizlikleri, fenalıkları yüzünden acınacak bir hale geldi. Düşmanla 
uğraşan hükümet ve onun taşra adamlart ise bunlara bakmiyor, bakamiyordu.

Hülâsa; ortallk o derece dumanlaştı ki bunlara seyirci kalmak doğru olmazdl. Artık bir (Ses)'in çıkması, haksızlıklara, zulümlere, ahlaksızlıklara karşı bağırması, son kerteye gelen zavallı müslümanların kurtuluş çarelerini araştırması lazim ve farz idi.... Isşte gazetemiz bu gibi düsüncelerin ve endişelerin tesiri altında çıkıyor"du. Onun gideceği yol; ahlâk yoludur.

"(Ses)'in dili (Sade Türkçe)'dir: O çapraşık dillerle uğraşmayacak, milletin, Anadolu köylüsünün söylediği tatl dil ile konuşacaktır."

Ses bir taşra gazetesi olarak siyasî konular ve karışık bahisleri İstanbul gazetelerine birakacak, bu hususlarda özet bilgi vermekle yetinecektir. Onun esas hedefî; toplumdaki hastalıkları düzeltmek, tefrikayı ortadan kaldırmaktır. Mukaddime mahiyetindeki bu makale, M. Akif tarafından gönderilmiş olan ve bundan sonra da gazetenin her sayısının başında yer alacak olan șu dörtlükle biter.

Düşman sesi duymak istemezsen,

Kardeş sesidir uyan bu sesten!

Kalkınca görür ki akşam olmuş.

Vaktiyle uyanmayan bu Ses'ten...

Hasan Basri (Çantay), daha sonra 1964'te yayınladığı Kara Günler ve İbret Levhası adlı eserinde (İstanbul, 1964, s. 5-7) Ses'i çıkarmasını, yine dönemin bir panoramasını çizdikten, özellikle de eşkiyalığın çok yayıldığından, köyler kasabalar basıldığından, bu nedenle tarlaya, bağa, bahçeye gitmekte sıkıntı çekildiğinden bahsettikten sonra; ben o günlerde Türk'ün çiğnenen haklarını müdafaa etmek üzere Balıkesir'de Ses adında bir gazete çıkardım. Bir kısım arkadaşlarımın; senin bir gazeten mi dünyayı düzeltecek, başına felaketler açacaksın, vazgeç, yapma demelerine rağmen gayretime devam ettim.

“Zaman oldu Türk'e hakaret eden istilacıların aleyhinde mecburi müdafaa yazılar yazdım. Vakit oldu Rum ve Ermeni vatandaşlarla karşllklı kavgalar ettim. Hele eşkiya hakkindaki yazılarım çok şiddetli idi." Halk ümitsizdi, Ümit vermeye çalıștım. O kara günlerde halâ ihtikârla, yağmayla uğraşanlar vardı. Onlarla mücadele ettim. Herkesin İttifak'ı Mukaddes'e, Millî Hareket'e çağırdım. Azınlıklar şımardıkça şımardılar. Ben yazıyor, yazıyordum ve Ses Türkiye'nin en ücra köşelerine kadar sokuluyor, okunuyordu. 
Gerçekten de Ses'in toplam 46 sahifelik koleksiyonuna, kısaca bile olsa, bakıldığında bu hedeflerin gerçekleştirildiği, söylenenlerin yapıldığı görülür. Ses'in çoğu Hasan Basri Hoca'nın kaleminden çıkmış olan baş makâleleri, halkımızı birliğe, beraberliğe; köylünün durumunu düzeltmeye, ezilen halka adil bir yönetimle yardım etmeye, fırsatçılara mani olmaya, kara borsayla, ihtikârla sonuna kadar mücadele etmeye, bilhassa da eşkiyalık hareketlerine son vermeye çağırır. $\mathrm{O}$ dönemde bölgemizi kasıp kavuran eşykiyaların faaliyetlerini isim isim ve adım adım takip etmek isteyenler Ses'e bakmalıdırlar.

Ses ile Hasan Basri Hoca her türlü uygunsuzluğa ve kötülüğe, kelimenin tam anlamıyla harp açmış gibidir. Bir örnek vermek gerekirse; 2 Ocak 1919 tarihli 12. sayısında harbi, zenginleşmek için fursat bilenlere karşı Muhtekirler Cezasız mı Kalacak? başlıklı geniş bir başmakale yayınlıyor. Burada dört yıl devam eden Cihan Savaşının, ahlâki yöndeki yıkıntıları üzerinde duran $\mathrm{H}$. Basri Hoca, bir taraftan Kafkasya'da, Irak'ta, Suriye'de, Galiçya'da, Romanya'da ve diğer cephelerde bu milletin evlatları düşmanla aslanlar gibi harpederken, öte yandan bir kısım muhtekirlerin bu durumu fırsat bilerek onların geride bıraktıkları aile fertlerine büyük sıkıntılar çektirdiklerini, yakınarak ifade etmektedir. Hoca'nın ifadesiyle; "Bu yağmalar, bu ihtikârlar milletin adeta yüzde doksan'ını züğ̈̈rt ve perişan biraktı̆̆ halde, yüzde onunun servetlere, ihtişamlara gark etti. Mesela vaktiyle beş kurus haftalıkla kahvecilik çırakliğı edenler, bugün başımızda birer lord kesildiler.

Bunlar milletin misır koçanı, ayrık kökü ile idâme-i hayata mecbur kaldığı zamanlarda kılçıklı ve yenmeyecek maddelerle karışı bakla unların en has un diye millete yutturdular ve mukabilinde milyonlar kazandılar." Bu kötü ve ahlaksızları doğru yola davet eden H. Basri Hoca, sulhün yapılmasıla cepheden dönecek olan milletin arslanlar gibi cesurca savaşmış evlatlarının bu durumu gördüklerinde, "Kükreyerek onların yüzüne tüküreceğini" hatırlatmakta, satırlarına şu dörtlükle son vermektedir.

Bir gün gelecek sen de perişan olacaksin, Ey gonca bu cem'iyeti her dem mi santrsin? Zalim yine bir zulme giriftar olur âhir. Elbette olur ev yikanin hanesi viran...

İhtikâr ve muhtekirler konusunu daha sonra da ele almảya devam eden Ses ve H. Basri Hoca 23 Ocak 1919 tarihli 15. sayıda, Balıkesir' 
de İhtikâr başlığı altında un fiyatlarının kasten ve aşırı biçimde yükseltildiği hakkında daha önce 12. sayısında bazı İstanbul gazetelerinde yayınlanan ve kendisinin de alıntı yaptığı haber üzerine, Belediye Başkanı ve Ticaret Odası Reisi Keçeci-zade Hafı Mehmet Emin Efendi' nin gönderdiği İhtikâr Hakkında Bir Cevap bașlığını taşıyan bir yazısını yayınlar. Bu yazıda Emin Efendi, un fiyatlarının yükselmesinin ihtikâr değil, ekonominin kendi kanunları gereği olduğunu ifade etmektedir. Gazetenin ilk sahifesinin hemen tamamına yakınını dolduran bu yazıyı, kanunî bir zorunluluğu olmadığı halde yayınlayan Hasan Basri Hoca, gazetenin bu sayısının geri kalan tamamında, 30 Ocak 1919 tarihli 16., 6 Şubat 1919 tarihli 17. sayılarında da genişçe bu konuları işlemiş ve hem Emin Efendiye cevap vermiş, hem de doğru ve milletin hayrına olduğuna inandığı fikirlerini ısrarla, sonuna kadar müdafaa edeceğini göstermiştir.

Ses gazetesinde H. Basri Hoca, haksız büyük kazançlar yanında, küçük çaplı ama fakir halka sıkıntı veren bazı uygulamaları da tenkit etmekten geri durmaz. Enteresan bir örnek ikinci sayıda MuhtarlaraImamlara başlığını taşır. Bu yazıyı aynen veriyoruz: "Muinsiz veya şehit maaşı alan ailelerin işini yaptı̆̆ımızdan veya yapacağımızdan dolayı bazılarımızın o. zavallılardan fazla para çekmekte olduğunu işitiyoruz.

Bu günahtır, zulümdür. Yalnızlık ve fakirlik yüzünden zaten sefalet içinde kalan o biçarelerden para almak değil, kendilerine her hususta yardım etmek din ve vatan borcumuzdur. Birde siz zulme kalkışırsanız -Muhtarlar, Imamlar- sonumuz ne olur? Şimdilik bu kadar yazıyoruz. Eğer bu halinizde yine devam edecek olursaniz, birer birer isimlerinizi yazmaktan ve kendinizi terbiye ettirmekten çekinmeyeceğimizi söyleriz."

Ses gazetesinde mahallî bazı haberler yanında Şekâvet başlığı al'tında sürekli olarak eșkiyalık hareketleri, sağlık, din hatta öğrencilerin ilgilerini çekmek için matematik ve geometri konularıyla İcmâl-i Siyasi İstanbul Yazıcımız Yazıyor başlığı altında Eşref Edib'in kaleme aldığı ifade edilen ülke genelini ilgilendiren siyasî haber ve yorumlar yer alıyordu. Fakat şüphesiz hepsinden önemlisi bilhassa da çoğu H. Basri Hoca'nın kaleminden çıkmış olan başmakalelerdi. Bunlar arasında; Gideceğimiz Yol, Asayiş Meselesi, Bugünkü Vazifelerimiz, Rumlar mı Mazlum? Zavall Kö̈ylülerimiz, Muhtekirler Cezasız mı Kalacak?, Hirsızlık, Yağma Devrinde Anadolu, Un Meselesi, İttifâk-ı Mukaddes, Neler Oluyor? Ayvalık Ahvâli-Anarşi, Kara İsa'nın Memleketi Hiç 
Bir Ecnebiye Verilemez ${ }^{1}$ ve Akif'in yazdığı Yeis ve Bedbinlik başlıklarını görürüz ki, bu başlıklar zaten içeriklerini de önemli ölçüde ortaya koymaktadırlar.

Ses gazetesinin kaç adet basıldığını bilemiyoruz. Fakat o sırada ülke geneline, hiç değilse gazeteler arası dağıtım yoluyla, yayılma imkânı bulduğunu tahmin etmek doğru olacaktır. Fakat onun Balıkesir ve çevresinde sürekli okunduğu ve belirli bir okuyucu topluluğuna muntazaman ulaştırıldığına șüphe yoktur. Bunu kaza ve köylerden gelen okuyucu mektuplarından kolayca anlamaktayız. H. Basri Hoca, gazetenin geniş halk topluluğuna ve bilhassa da köylülere ulaştırılmasında ısrarlı olduğunu görüyoruz. Nitekim 12 ve 19 Aralık 1918 tarihli 9 ve 10 numaralı Ses'de bu husus 1srarla vurgulanmakta ve köylülere ulaşmak üzere Perşembe günleri çıkartılan gazetenin aynı şekilde bir nüshasının da Sevgili Köylülerimize bașlığıyla Salı günleri basılacağı ifade ediliyordu.

Ses gazetesinde Hasan Basri (Çantay) dışında Eşref Edip, Mehmet Akif, Abdullah Esad, Sebati, Vacid Nazmi ve isimleri belirtilmemiș Erdek, Balya, Bandırma, Ayvalık muhabiri gibi yazarların yazdıklarını görüyoruz.

Sonuç olarak şunu ifade edebiliriz ki, Ses gazetesinin o sıkıntılı günlerde halkımızı bilgilendirmek, ülke geneli ve bölgemizdeki gẹlişmeler konusunda aydınlatmak; yakın bir gelecekte bașlayacak olan silahlı mücadeleye onları ruhen hazırlamak, milli amaçlar yönünde birliğin sağlanmasını temin istikametinde önemli bir görev ifa etmiș olduğuna şüphe yoktur.

\section{SEÇILMISS BİBLIYOGRAFYA}

Ahmet Keskin, Milli Mücadelede Balıkesir, Ankara, 1991, Basılmamış Lisans Tezi, A.Ü. İlâhiyat Fakültesi Kütüphanesi.

Ali Erdil, Balıkesir Basın Tarihi ve Ses Gazetesi, Ankara, 1989, Basılmamış Lisans Tezi, A.Ü. İlahiyat Fakültesi Kütüphanesi.

Aydın Ayhan, İzmir'in İşgali Surasında Balıkesir, Milli Mücadelede Balıkesir, İstanbul, 1990, s. 31-52.

1 (Bu makaleler yazarın, Türk Dili'nde yayınladığı bazı makaleleriyle birlikte Kara Günler ve ibret Levhası, İstanbul,.1964, adlı eserinde yer almaktadir) 
Aydın Ayhan, Hasan Basri Çantay, Merve, Y11 1, S. 2 (Balıkesir May1s-Haziran 1993), s. 4-8.

Bayram Bayraktar, Mütareke'de Ses Gazetesi, Tarih ve Toplum, S. 93 (Eylül 1991 İstanbul), s. 52-56.

Cemal Kutay, Milli Mücadelede Devletleşen Belde: Balıkesir, Millî Mücadelede Balıkesir, İstanbul, 1990, s. 9-30.

Hasan Basri Çantay, Kara Günler ve İbret Levhası, İstanbul, 1964.

Hasan Basri Çantay, Akifname, İstanbul, 1966.

İhsan Ilgar, Mütarekede Yerli ve Yabancı Basın, İstanbul, 1973.

Kemal Özer, Kurtuluş Savaşında Gönen, Balıkesir, 1964.

M. Vehbi Bolak, Milli Mücadelede Balıkesir, Millî Mücadelede Balıkesir, İstanbul, 1990, s. 157-178.

Mediha Akarslan, Milli Mücadelede Balıkesir, Ankara, 1988, Yayınlanmamış Doktora Tezi, A.Ü. İnkılâp Tarihi Enstitüsü Kütüphanesi.

Murat Ali Doğan, Milli Mücadelede Balıkesir, Ankara, 1977, Yayınlanmamış Yüksek Lisan Tezi, A.Ü. İnkılâp Tarihi Enstitüsü Ktp.

Mücteba İlgürel, Balıkesir Kongrelerinin Milli Mücadeledeki Hizmetleri, Millî Mücadelede Balıkesir, İstanbul, 1990, s. 179-186.

Mücteba Uğur, Hasan Basri Çantay, Ankara, 1993 (Baskıda). Bu çalışmasından neşrinden daha önce faydalanma firsatını bana verdiği için, sayım hocama teşekkürlerimi sunmayı yapılması gereken aziz bir görev bilirim.

Ses Gazetesi Kolleksiyonu

\section{GIDECEĞİMIZZ YOL}

(Ses Gazetesinin İlk Sayısındaki Başmakale)

Düşmanla senelerden beri yaptığımız ve Allah'm merhameti ve inayeti ile hayırlı olarak nihayetine eriştirmek üzere olduğumuz kanlı muharebe; bizdeki bir çok çeşitli kabiliyetleri meydana çıkardı. Bu kabiliyetlerin en kısa ve kestirme tecellisi (uyanıklık)'tır: Filhakika din kardeşlerimizden mühim bir parçası ticarete, sanaata, çiftçiliğe koyuldu, memleketin ve devlet hazinesinin gelirini çoğaltmaya, yaşamanın yol- 
larını anlamaya, hülasa: Zengin olmaya başladı. Denizlerin, karaların kapanması bize kendi yağımızla kavrulmak dersini de vermiști: Yiyeceklerimizi, içeceklerimizi, giyeceklerimizi kendimiz bulmaya ve hazırlamaya mecbur kaldık. Eskiden yiyeceğimiz zahirenin yüksek bir kısmını ecnebî memleketlerinden getirmeye alıştığımız ve Türkiye'nin yiyecekte bile dışarıya muhtaç olduğunu zannetmekte olduğumuz halde, bu koca muharebe bu yanlış zanlarımızı düzeltmeye, memleketlerimizde ne büyük hazineler olduğunu göstermeye bașladı. (Son iki kelime tahminen okundu). Daha dün yabancı elbisc giymekteyken, harp senelerinde biraz kaba ve fakat sağlam yerli kumaşlarını giymekle ruhumuzda büyük bir zevk' duyduk.

Hülasa: Harp bizi uyandırdı ve benliğimizi bize tanıttı. Fakat bu uyanma ve tanıma içinde bir çok hırslar, ihtiraslar ve ahlaksızlıklar da sokulabilmiști. Kasalarımızı dolduran kâğıt paralar eski ruh temizliğimizi -maatteessf- bozdu. Herkes (nefsî, nefsî) demeye başladı, (ümmetî, ümmetî) diyen büyük yürekli bir adam kalmadı! Fukaranın çektiği elemler karşısında evvelden vicdanı sızlayan hamiyet erlerinin yumuşak ve merhametli kalpleri -taş gibi- katılaştı, kömür gibi karardı. Teâvün (yardımlaşma) ve tesanüt denilen o seciye ve huylarımız göğe çekildi. Bir taraftan uyanıklarimız -her ne suretle olursa olsundaha fazla para kazanmak hülyâsı ile uğraşırken, diğer taraftan millet ve milletin çokluk tarafı hayatın ve açlı̆ı̆ ağır ve ezici yükleri altında eziliyor, sessiz bekliyordu.

Zenginlik vâkıa büyük bir fazilet idi. Fakat halkın kanından ve iliğinden sorulan bu şey artık bir rezâlet şeklini aldı.

Sonra: Bir çok sebepler yüzünden diğer kötülükler de arttı. Eskiden -meselâ- Balıkesir'de fahişelerin sayısı üçü geçmediği halde, son zamanlarda yüzlere vardı! Bunlar memleketimizin temiż adını kirletti. (Balıkesir) ta trenlerde, vapurlarda hatta İstanbul ve (Bey) oğlu sokaklarında fena bir surette anılmaya başladı.

$\mathrm{Bu}$ haller bizim çok ağırımıza gidiyordu. Balıkesirli bir müslüman olmak itibarıyla hakikaten sıkılıyorduk. Köylerde devam eden hastalıklar, yanlıș itikatlar, fenalıklar dahi -bizde çokluk tarafını tutan- köylülerimizin varlığını kemiriyor, onları yok ediyordu: Köylüler bir taraftan eşkiyâlığın zulümleri, ihtikârcıların dolapları yüzünden, öbür taraftan da kendi bilgisizlikleri, fenalıkları yüzünden acınacak bir hale geldi. Düşmanla uğraşan hükümet ve onun taşra adamları ise bunlara bakmiyor, bakamiyordu. 
Hülasa: Ortalık o derece dumanlaştı ki: Bunlara seyirci kalmak doğru olmazdı. Artık bir (Ses)'in çıkması, haksızlıklara, zulümlere, ahlâksızlıklara karșı bağırması, son kerteye gelen zavallı müslümanların kurtuluş çarelerini araştırması iazım ve farz idi. Harp gibi âdetin üstünde bir beliyyenin başımıza musallat eylediği bu fenalıkların kökleşerek (beş altı kelime okunamadı) sonra da devamı -Allah göstermesinbir daha meydana çıkmamak üzere batmamız demek idi. İște gazetemiz bu gibi düşüncelerin ve endişelerin tesiri altında çıkıyor!

Onun gideceği, yürüyeceği ana yol şudur: Ahlak yolu!.,

Evet: Gazetemiz yolunu şaşıran dindaşlarına pürüzsüz ve doğru yolları göstermek, fenalık edenlerle -insanca, kardeşce- uğraşmak, ezilen zavallılarla dert ortağı olmak işini güdecek ve bu yolunda yürürken uğrayacağı engelleri -gücünün yettiği kadar- tabii kaldırmaya çalışacaktır. Aynı zamanda (Ses) bilgi ve meşru kazanç usul ve ihtiyaçlarımızın öğrenilmesi uğrunda da yazılar yazacak, gençlerimizi ve daha ziyade köylülerimizi -elinden geldiği derecede- uyandırmayı her şeyden üstün bir vazife bilecektir.

(Ses)'in dili (sade Türkçe)'dir. O, çapraşık dillerle uğraşmayacak, milletin, Anadolu köylüsünün söylediği tatlı dil ile konuşacaktır.

Siyasî ve çetin bahislerle iştigali İstanbul gazetelerine bırakacak, ancak umumî cereyanların aldığı şekiller hakkında her hafta kısaca malumat vererek, asıl ehemmiyet gözünü ise (iç hallerimiz)'e çevirecektir. Çünkü: Onun kökleşmiş düşüncesine göre (içimiz iyi olmadıkça dışımızın düzene girmesi mümkün değildir). Biz, bütün müslümanlar şu nazik ve tehlikeli zamanlarda birleşmedikçe, fena hallerimizi değiştirmedikçe, ahlakımızı iyi temeller üzerine kurmadıkça... dünyanın bütün zengin parçalarını alsak yine hiçtir! Halbuki: Bugün sulh masasının başında oldukça ehemmiyetli zararlara uğrayarak ayrılmamız da -Allah korusun- ihtimal içindedir. Ya bu hal karşısında yine fenalıklarla, ahlaksızlıklarla, dedikodularla vakit geçirirsek sonumuz ne olur?

Milletleri yıkan yaman șey: Ahlaksızlıktır. (Kale içeriden alınır) sözü ne kadar doğru ise (içeriden verilir) sözü de o kađar doğrudur.

Umarız ki: Okuyucularımız -hiç bir şahsî ve siyasî tesir altında bulunmayan ve bütün gayesini müslümanlığın yücelmesinden, kurtulmasindan ibaret bilen- gazetemizin fazla rağbet kazanmasına ve hele köylerde muallimlik veya imamlık eden hocalarımız en çok köylünün derdini anlayan (Ses)'in köylü ağalarının kulağına girmesine -Allah 
rızası için- çalışılar, bu suretle de dinî, millî, manevî bir hizmet (?) yaparak bu suretle en büyük bir sevap kazanmış olurlar. Yardım Allah'tandır.

Düşman sesi duymak istemezsen,

Kardeș sesidir uyan bu sesten.

Kalkınca görür ki akşam olmuş,

Vaktiyle uyanmayan bu sesten.

Hasan Basri

Ses, Sayı 1.

17 T. evvel $1334 / 11$ Muharrem 1337. 


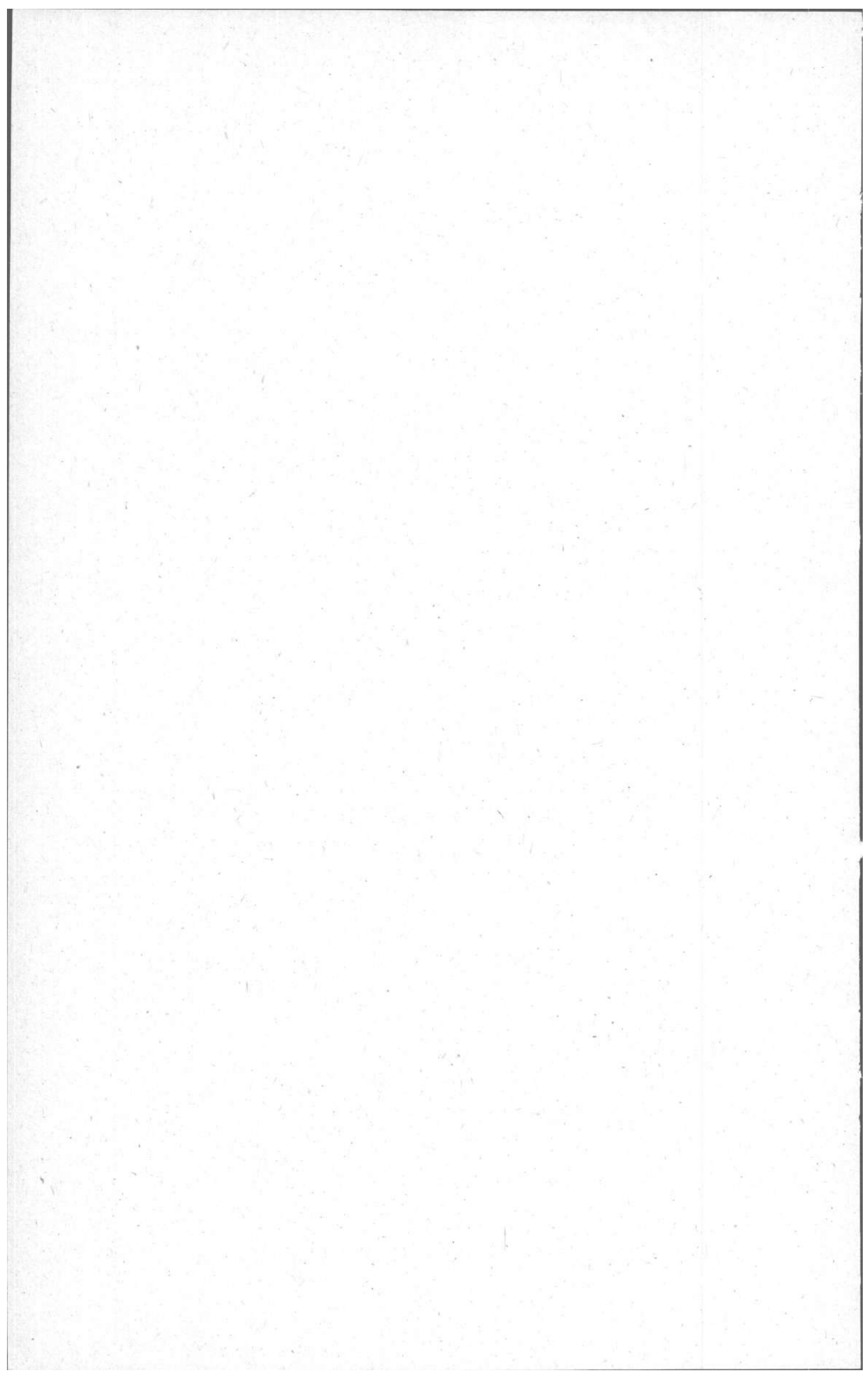

